\title{
Hindering Factors that Prevent College English Students from Participating in Class Discussions: A Case at Jiangsu University, China
}

\author{
Solange E. Guerrero ${ }^{1, *}$ \\ ${ }^{1}$ School of Foreign Languages, Jiangsu University, P. R. China \\ *Correspondence: School of Foreign Languages, Jiangsu University, 30, Xuefu Road, Zhenjiang, Jiangsu 212013, P. \\ R. China. E-mail: 5102160403@stmail.ujs.edu.cn
}

Received: April 17, 2019

Accepted: May 14, 2019 Online Published: May 23, 2019

doi:10.5430/jct.v8n2p62

URL: https://doi.org/10.5430/jct.v8n2p62

\begin{abstract}
During several non-participant observations of two advanced College English classes at Jiangsu University, it was noticed that most of the students did not engage in class discussions. To ascertain what the problem was, but from learners' perspectives, this research was conducted. Seventy-one students enrolled in College English at Jiangsu University volunteered to partake in this work. A self-administered questionnaire was used to gather the data. The findings indicate that most of the respondents did not take an active stance in class discussions because of their lack of knowledge on strategies to bear their thoughts or opinions. Other expressed that they did not know about the topics to discuss in class, and that was a significant barrier to their performance. Besides, some participants doubted to speak in class. That can be linked to their shyness. Knowledge about these findings is helpful for teachers and College English authorities to examine what kind of training should be offered to students and teachers to make steady improvements.
\end{abstract}

Keywords: class discussion, College English, hindering factors, Jiangsu University

\section{Introduction}

College English is an official program for non-English majors in China. It is divided into six bands: bands 1-4 are compulsory for undergraduate students, while bands 5 and 6 are elective for postgraduates (Yang \& Yuen, 2014, p. 498). The program details what students must attain during their college years. However, it has undergone significant reforms (Huiyin, 2016, pp. 78-79) in its curriculum's structure and content including changes in teaching objectives, teaching approaches, the form of the assessment, and the teachers' and learners' roles (Han \& Yin, 2016).

For instance, the 2007 guideline stressed, as intermediate requirements for the development of the speaking skills, that learners must learn how "to express their personal opinions, feelings, and views, to state facts and reasons" (Department of Higher Education, 2007, pp. 25-27). The 2015 guideline also proposes to advance learners' speaking skills. It contains three levels of teaching objectives. The second and third objectives state that students should "be fluent and efficient in their oral...communications", as well as, "learn how to analyze, synthesize and compare information from different sources in order to form ideas" (Huiyin, 2016, p. 83). Therefore, students must gain these skills while attending College English and a meaningful way to do it is through class discussions.

In general terms, a discussion is described as "the examination or consideration of a matter in speech or writing" (Discussion, n.d.). In class, discussions are strongly encouraged through verbal discourse exchanges. However, they are effective when the interaction is from peer to peer (Barton, Heilker \& Rutkowski, n.d). Class discussions are "one of the most frequently used and often embraced pedagogical strategies" (Dallimore, Hertenstein \& Platt, 2004, p.103). They can present formats of a whole class, peer to peer or in small groups where a monitor [an assigned student or teacher] should guide them to achieve the purpose of the activity.

Techniques used to involve students in class discussions range from "question-and-answer sessions" (Putiman, 2005), digital media (Lee \& Martin, 2017), technology-mediated task-based (Chen \& Lin, 2018) to discussions of literature (Mart, 2019), to name a few. Besides, readings are used to help learners to acquire "vocabulary...to think and speak with more words" (Akman \& Alagöz, 2017, p. 21) and be active in a class discussion. 
Since "development and learning are 'co-constructed' in social interactions" (Muller, Perret-Clermont, Tartas \& Iannaccone, 2009, p. 75), as a kind of interaction, there are some advantages associated to class discussions. For instance, learners can advance their critical thinking skills (Howard, 2004) and boost their knowledge on general issues and strategies to express their thoughts (Abdulbaki, Suhaimi, Alsaqqaf \& Jawad, 2018). Likewise, they can help to enrich the quality of the argumentative skills by testing their ideas and learning to provide evidence to support them (Omatseye, 2007). Extra benefits are linked to class discussions. Brookfield \& Preskill (1999) point out four more:

(1) to help participants reach a more critically informed understanding about the topic or topics under consideration; (2) to enhance participants' self-awareness and their capacity for self-critique; (3) to foster an appreciation among participants for the diversity of opinion that invariably emerges when viewpoints are exchanged openly and honestly; and (4) to act as a catalyst to helping people take informed action in the world. (p.3)

Class discussions do not only benefit students to foster new knowledge and advance their argumentative and social skills. Dallimore, Hertenstein, \& Plat (2017) indicate that learners take an active stance during the class, validate and clarify their background knowledge, and "remember and retaining information" (para. 3). Moreover, this kind of interaction supports learners to build a scaffolding that will allow them to be "aware of their problems" to solve them (Mart, 2019, p. 849).

Although the advantages of applying class discussions as a pedagogical strategy, at times, getting students involved in those discourse exchanges is a challenge. Factors such as the "fear of making mistakes" (Savaşçi, 2014, p. 2686), or the "lack of interest in the material" (Zakrajsek, 2017, para. 12) covered in the class may become the walls that restrain students from engaging in class discussions. However, that depends on the educational setting. For instance, a constant assertion is that Chinese students who are learning English abroad (or pursuing a degree where English is the means of instruction) and at home through the College English program have difficulties to use the language. It is highlighted the "poor spoken English" (American TESOL, 2015, para. 4) of students' as one of the leading causes for their lack of engagement in class discussions. Though, that is an arguable claim due to some findings.

On the one hand, researchers affirm the previous claim. They declare that students are reluctant to join class discussion due to challenges with their English language proficiency (Kim, 2006). Some students demonstrate "low communicative competence" (Zhang, n.d, p. 4). Others lack the confidence to apply oral communication (Wang, 2010), suffer from anxiety (Mak, 2011), or "are often marginalized and disadvantaged" (Qi, 2018, p. 799) during the discourse exchange. However, the problem is linked to conventional teaching approaches focused on the teachers' role and culture (Zhao Y., 2007; Xie, 2010).

Also, students' lack of preparedness on the topic to discuss in class is another drawback that does not permit them to feel confident to talk (Peng, 2012). In many of the cases, erroneously, those assertions are generalized to all Chinese students learning the English language.

On the other hand, Zhao W., Mok, \& Cao (2016) indicate that students' hesitation in engaging in class discussions is not related to conventional teaching methods because "after 15 years of reform, teachers, students, and classrooms in China have changed a lot" (p. 89). Therefore, rather than cultural or lack of the student-centered approach, the problem can be related to how the lesson is delivered (Cheng, 2000) because many students are willing to participate in class discussion ("Reticence in Chinese EFL students," 2014). Though, others are not motivated "towards EFL speaking" (Rashid, Bao, \& Jelani, 2018, p, 78). Hence, the problem regarding reluctance is still latent.

For example, during some non-participant observations of two advanced classes from the College English program at Jiangsu University in China that aimed to test a new teaching approach, it was noticed that many students did not participate in class discussions. The questions to start the discourse exchange were clear, direct, and concise. Besides, students had time to think about what was asked to express their thoughts or standpoints. However, most of the time, students were in silence or refused to take part in the class discussions. Therefore, the questions emerged: What hindering factors do prevent students from participating in class discussions? What is the case for other learners enrolled in the College English program at Jiangsu university? To address these questions, this research was conducted.

\section{Method}

\subsection{Sampling Procedure}

This research work focused on unveiling hindering factors that prevent students in College English at Jiangsu 
University from participating in class discussions. In order to attain that purpose, convenience sampling was applied. Participants were anonymous and recruited through e-mail and WeChat solicitation. In total, 71 students replied to the calling for this research: $50.7 \%$ (36) of the respondents identified themselves as female and $49.3 \%(35)$ as male.

As a specification, the sampling for this work is not a representation of the original population of interest, which is all the students enrolled in College English at Jiangsu University. However, it was gained, as much as possible and from students' perspectives, valuable insights into aspects that prevent them from participating in class discussions. Therefore, the interpretation of the results should be limited to the participants of this research

\subsection{Data Collection and Analysis}

The data collection and analysis for this work followed a cross-sectional design supported by a survey. The self-administered questionnaire contained ten questions. They were written in English and had the format of dichotomous, multiple choice, filter or contingency questions, and a 5-point Likert scale. The survey was distributed online and processed through Survey Monkey. The results were represented in bars chart.

\section{Results}

Participants in this research were enrolled in College English 2018 Spring semester at Jiangsu University in China. They comprise a variety of bands: College English Band 1 (9.9\%); College English Band 2 (12.7\%); College English Band 3 (15.5\%); College English Band 4 (15.5\%); College English Band 5 (9.9\%); and College English Band 6 (36.6\%). Through the participants' responses, it was discarded and revealed factors that prevent them from participating in class discussions. The findings are organized and reported by sections.

\subsection{Section 1: On the Speed with Which Instructors Presented the Course Material}

A critical aspect of the classroom is the speed used to present the content of a course and instructions to students to perform in-class assignments such as class discussions. When both aspects are not consistent, good learning outcomes may be reduced. Respondents, $7.0 \%$ (5), indicated that their teachers used a slow speed to share the materials of the course, only a $1.4 \%$ (1) indicated it was too slow, $85.9 \%$ (61) normal, and a $5.6 \%$ (4) fast. None of the respondents indicated that their teachers' speed was too fast.

\subsection{Section 2: On the Difficulties While Taking the Courses at the College English Program}

\section{Did you find any of the following aspects difficult while taking the English course?}

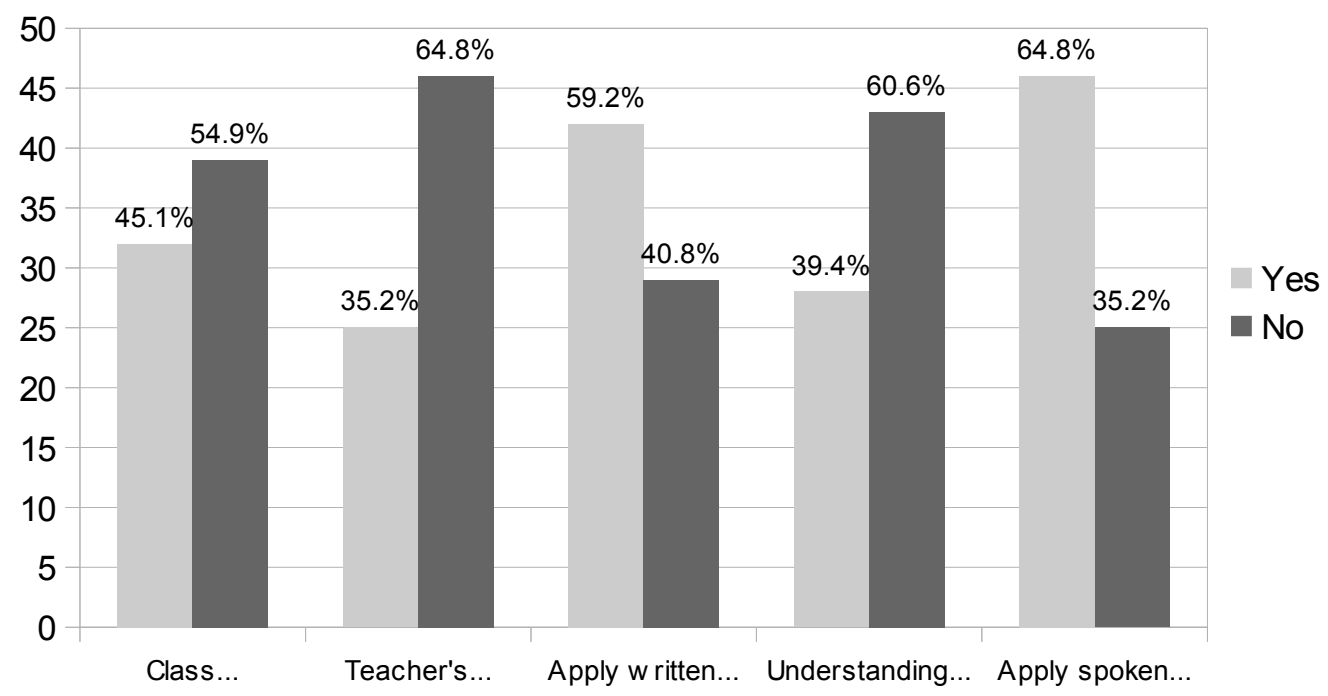

Figure 1. Difficulties While Taking the College English Course $(n=71)$

A course contains components that may become an advantage or drawback if they are not well-organized, taken into account, or put into practice to attain a particular set of goals for the lesson. As represented in Figure 1, five components were analyzed: (1) class content; (2) teacher's explanations on the content; (3) apply written English 
language to complete in-class activities; (4) understanding the instructions given by the teacher to accomplish an activity; and (5) apply spoken English language to complete in-class activities. In total, $45.1 \%$ (32) of the respondents found component 1 [class content] difficult while $54.9 \%$ (39) expressed the contrary. Besides, the results showed that two components were the main walls for students while taking the course in College English: aspect 3 [apply written English language to complete in-class activities] 59.2\% (42), and aspect 5 [apply spoken English language to complete in-class activities] $64.8 \%$ (46).

\subsection{Section 3: On the Interactions in the Classroom}

Interactions constitute an important part of a class. Through them, learners can develop social and linguistic skills, as well as, gain new knowledge. According to the findings, $(84.5 \%)$ of the respondents indicated that there were interactions in their courses and (15.5\%) expressed otherwise. The three interactions mostly happening in the class were: (a) teachers asking questions to students (83.1\%); (b) class discussions (60.6\%); and (c) problem-solving (56.3\%). Other interactions that happened while taking courses in College English are detailed in Figure 2 where it is, also, described the numbers of responses per option. The option "Other (please specify)" was displayed in the table to represent the total of responses, but the respondent only indicated "it is OK" as an answer.

\section{What kind of interactions were mostly happening in the classroom? (Check all that apply)}

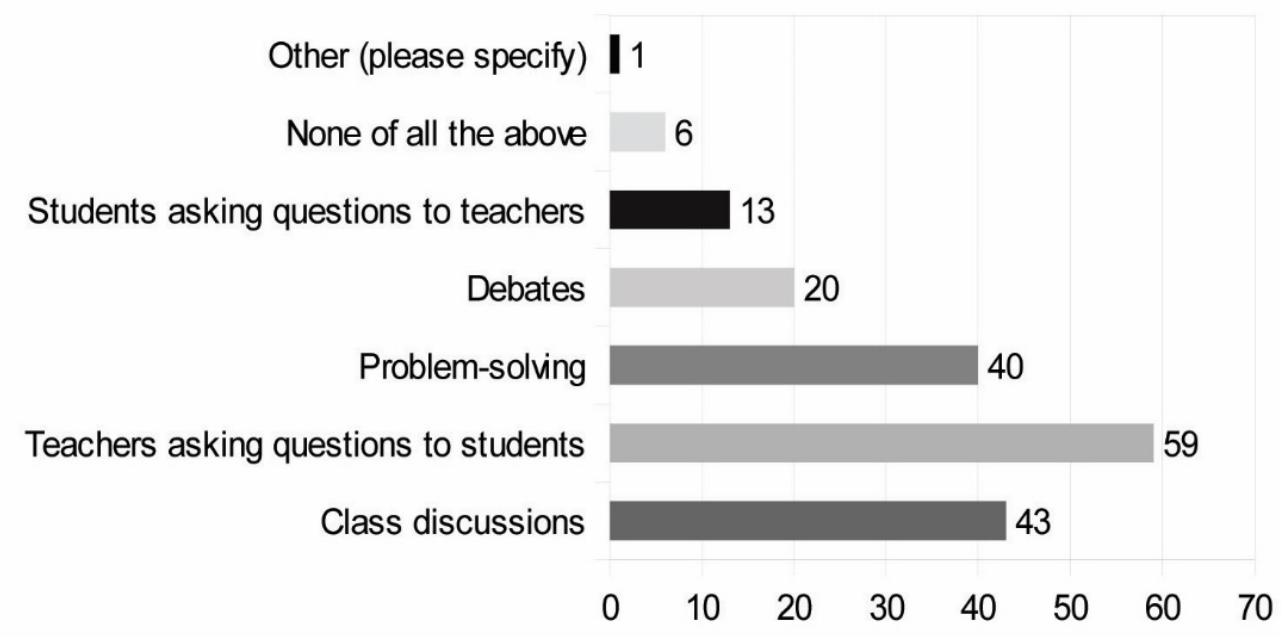

Figure 2. Interactions Mostly Happening During Classes $(n=71)$

\subsection{Section 4: On the Frequency in Which Some Tasks Are Encouraged to Hold a Discussion}

Class discussions were the second interaction mostly happening in the class (60.6\%). In a class discussion, some tasks play an essential role to have a meaningful discourse exchange. Five tasks were taken into account for this research. They are summarized in Figure 3, including the frequency in which those activities were encouraged to perform. The response - sometimes - was the most optioned by the respondents to rank the frequency in which some tasks were prompted to perform in class. They are described as follows: express a comment on something (43.7\%); ask critical questions to your classmates (42.3\%); discuss a topic with your classmates (40.8\%); ask critical questions to the teacher about the topic studied (36.6\%). For the task - explain the reason behind communicating an idea - the percentage of respondents showing the frequency (often) was $31.0 \%$, and $29.6 \%$ for (sometimes). However, all the activities were ranked low in the frequencies (usually) and (always). 
During the lessons, how often did your teacher ask you to do the following?

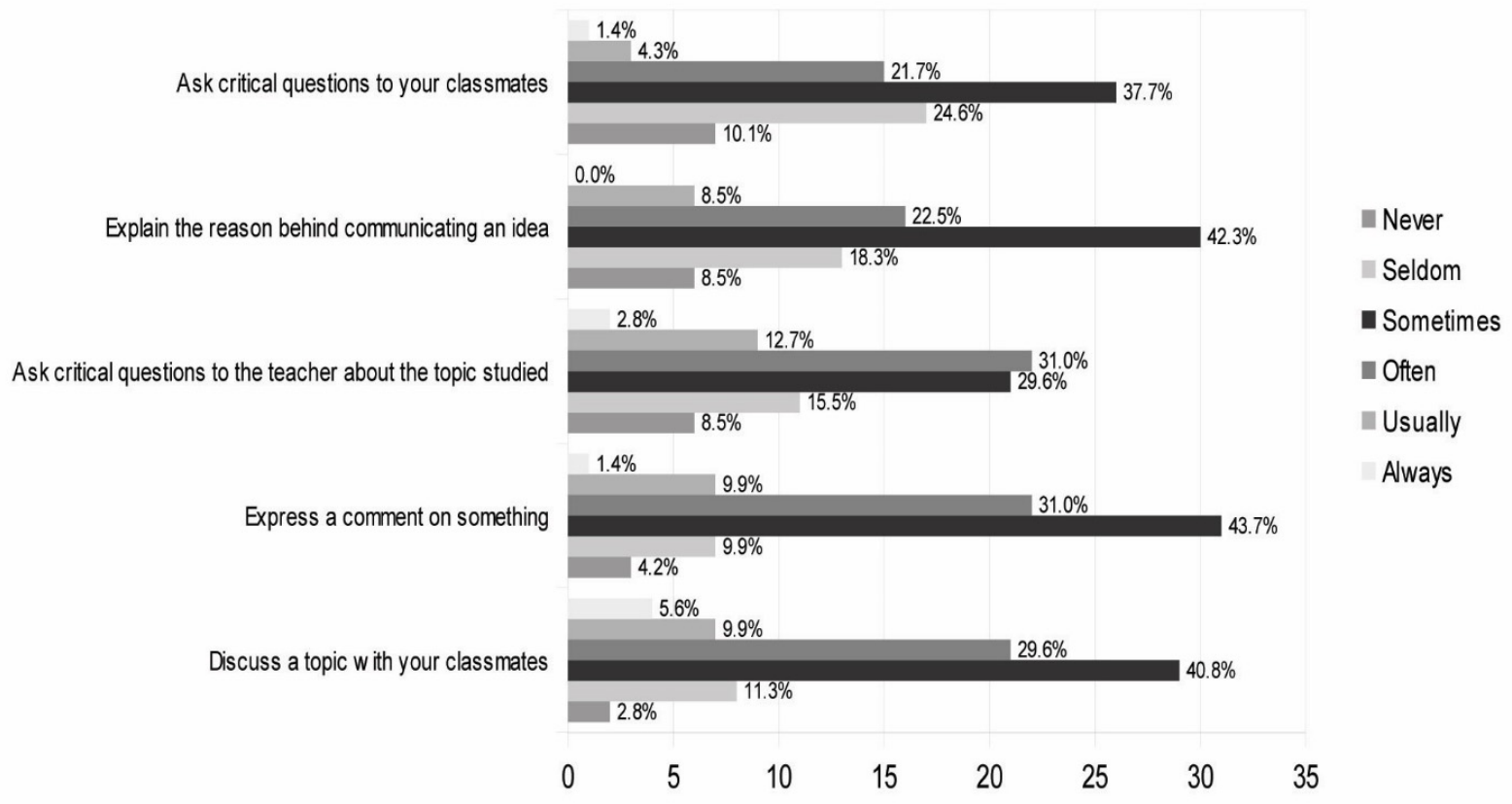

Figure 3. Frequencies in Which Some Tasks to Hold a Discussion Are Encouraged ( $\mathrm{n}=71)$

\subsection{Section 5: On the Aspects Preventing Students from Participating in Class Discussions}

Even though $60.6 \%$ of the respondents expressed they held class discussions while enrolled in College English courses, they also exposed hindering factors that prevented them from participating in those discourse exchanges. The factors are displayed in Figure 4 according to the number of responses per option and described as follows: the lack of knowledge on strategies to hold a discussion 56.3\% (40), followed by, no general knowledge on the topic to discuss $47.9 \%$ (34), doubts in speaking 39.4\% (28), shyness 38.0\% (27), and no experience in discussions $15.5 \%$ (11). For the option 'Other (please specify),' some respondents 7\% (5) expressed other hindering factors such as "boring," "worried about making mistakes in communication," "time limitation," and "worried that I cant speak well."

What aspects did not allow you to participate in class discussions? (Check all that apply)

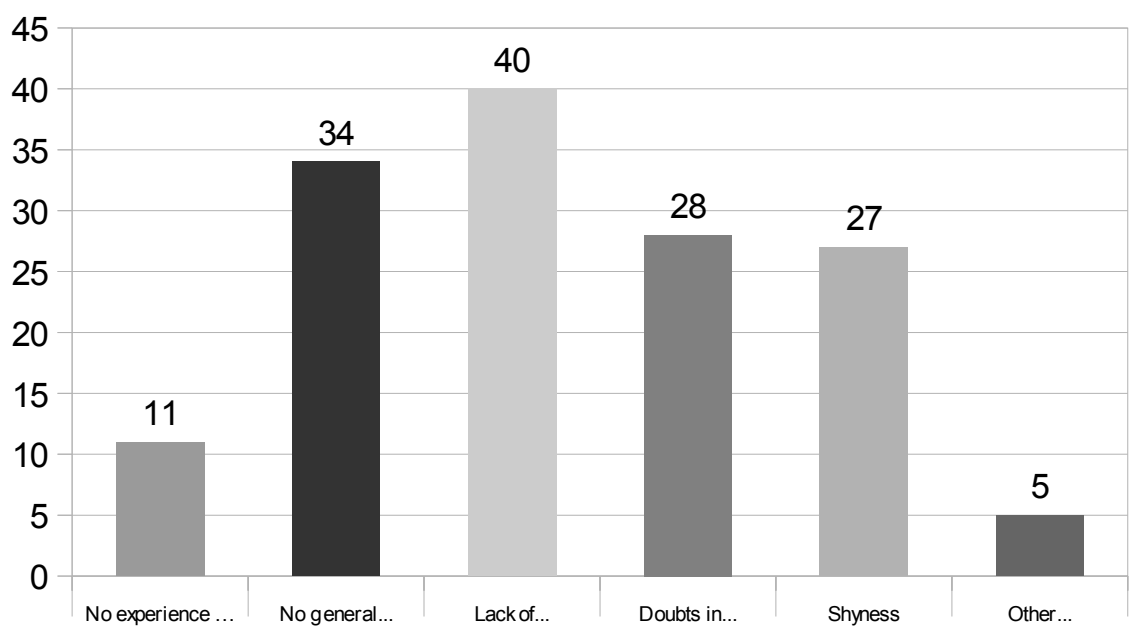

Figure 4. Aspects That Prevent Students from Participating in Class Discussions $(\mathrm{n}=71)$ 


\section{Discussion}

In classroom practice, strategies "represent the 'big ideas' that support the students' listening, speaking, reading and writing skills" (Herrera \& Murry, 2014. p. 186). They are a tool to perform a task for a specific academic purpose. As a pedagogical strategy (Dallimore et al., 2004), class discussions can assist students to build a scaffolding towards their learning advancement and the development of their speaking and argumentative skills. In a discussion, teachers monitor (Omatseye, 2007) how students assimilate the information covered during classes. However, that is a challenge because, sometimes, students are "not well versed in how to talk to and listen to each other, in how to navigate and negotiate and discuss issues of serious consequence and work toward answers among equals" (Barton et al., p. 2). The findings here support that assertion by revealing the lack of knowledge on strategies to hold a discussion $(56.3 \%)$ as the first factor that prevented students in College English from participating in class discussions. Strategies here, also, refer to the detailed sketch, steps or procedure designed to "retention \& retrieval of knowledge and performance" (Rigney, 1978, p. 165). Knowing about the procedure can serve as a supportive structure to engage in a class discussion. Those include knowing how to ask critical questions from peer to peer, know how to criticize opinions, take notes for discussion, and organize and express ideas (The Learning Center, n.d.), to mention a few. Also, learners were not used to explaining the reasons behind their idea (see figure 3) because they unknown formats to do so.

Furthermore, when students do not know about the topic to discuss, as shown through the findings (48\%), it is difficult to participate in a class discussion actively. Preparedness before and during class is a self-responsibility. It is the responsibility of the students. Academic background knowledge from previous courses, self-education on multiple topics or knowledge from the material assigned before attending class is an essential tool to facilitate learning. Unfortunately, sometimes, students are ill-prepared before attending classes because they do not review the assigned material to hold a discussion, "as a consequence, they may take a passive stance, the discussion can fall flat, and learning can be diminished" (West, 2018, p. 146). That "passive stance" may also lead to the results as asserted above because of the lack of learners' readiness during the class to take part in a discussion. In every class, there are the "so-called screen addicts...browsing products..., texting friends..." (Yan, 2017, para. 1) or doing homework for another subject to mention a few. Therefore, they do not know what the teacher talks about or how the flow of the class goes. Moreover, they do not feel confident or motivated to freely participate in this kind of interaction because "they are only half-present (if that)" (Lang, 2017, para. 6).

Relating the first two factors [the lack of knowledge on strategies to hold a discussion and no general knowledge on the topic to discuss], it is understandable that the next factor preventing students from participating in class discussions was doubts in speaking. That may have been the result of not knowing what to say or not knowing how to carry out thoughts, opinions, standpoints, and so forth; added to students' shyness (38.0\%) and the difficulties at applying spoken the English language to complete in-class activities (see figure 1).

All those factors become the affective filters or state of mind that affect students' "self-confidence...and motivation...to do better in second language acquisition" (Krashen, 1982, p. 31), and not allowing students to have a holistic performance and development in the classroom or do not allow them to develop their potentialities.

\section{Conclusion}

College English program in China requires students to be skillful in the language studied. Plus, they must learn how to analyze information to form ideas and exchange them. Those purposes are reachable through class discussions. However, some students enrolled in College English at Jiangsu University during the 2018 Spring semester claimed that it was a challenge. The findings revealed that aspects such as lack of knowledge on strategies to hold a discussion, no general knowledge on the topic to discuss, doubts in speaking, and shyness prevented learners from participating in class discussions. That demonstrates that training should be offered to students but from the beginning of their College English years, because the lack of knowledge and regular practice on class discussions may become a permanent shortcoming for them. Therefore, it is impossible for learners to progress in ignorance. By providing training, students can build confidence and improve their skills to discuss in class with their peers while they gain new knowledge and strengthen their social skills.

This work generated some questions that can serve as a reference for future research. Those are: What are the different structures and strategies that teachers apply to conduct class discussions? What do teachers do to reduce students' affective filters such as shyness? What kind of training and support do teachers receive from College English authorities to carry out class discussions? 


\section{Acknowledgments}

This research did not receive grants from any funding agency in the public, commercial, or not-for-profit sectors.

\section{References}

Abdulbaki, K., Suhaimi, M., Alsaqqaf, A., \& Jawad, W. (2018). The Use of the Discussion Method at University: Enhancement of Teaching and Learning. International Journal of Higher Education, 7(6). https://doi.org/10.5430/ijhe.v7n6p118

Akman, Ö., \& Alagöz, B. (2017). Relation between Metacognitive Awareness and Participation to Class Discussion of University Students. Universal Journal of Educational Research, 6(1), 11-24. http://doi.org/10.13189/ujer.2018.060102

American TESOL. (2015, July 10). Causes and Solutions to Poor Spoken English among Chinese Students. Retrieved from https://americantesol.com/blogger/tesol-viewpoint-causes-and-solutions-to-poor-spoken-english-among-chinese -students/

Barton, J., Heilker, P., \& Rutkowski, D. (n.d.). Fostering effective classroom discussions. Retrieved from https://www.holycross.edu/sites/default/files/files/centerforteaching/discussion_readings.pdf

Brookfield, S., \& Preskill, S. (1999). Discussion as a Way of Teaching: Tools and Techniques for Democratic Classrooms. San Francisco: Jossey-Bass.

Chen, T.-H., \& Lin, C.-C. (2018). Enhancing L2 English learning through mobile-assisted TBLT: EFL learners' perspectives. The Journal of Asia TEFL, 15(2), 453-461. http://dx.doi.org/10.18823/asiatefl.2018.15.2.13.453

Cheng, X. (2000). Asian students' reticence revisited. System, 28(7), 435-446. https://doi.org/10.1016/S0346-251X(00)00015-4

Dallimore, E. J., Hertenstein, J. H., \& Platt, M. B. (2004). Classroom participation and discussion effectiveness: student-generated strategies, Communication Education, 53(1). https://doi.org/10.1080/0363452032000135805

Dallimore, E. J., Hertenstein, J. H., \& Platt, M. B. (2017). How do Students learn from participation in Discussion? Faculty $\quad$ Focus. Retrieved from https://www.facultyfocus.com/articles/effective-teaching-strategies/students-learn-participation-class-discussion I

Department of Higher Education, Ministry of Education of the People's Republic of China. (2007). College English Curriculum Requirements. Beijing: Higher Education Press.

Discussion. (n.d.). In Collins Dictionary online. https://www.collinsdictionary.com/dictionary/english/discussion

Han, J., \& Yin, H. (2016). College English Curriculum Reform in Mainland China: Contexts, Contents and Changes. Journal of Asian Education Studies, 1(1), 2424-8487. https://doi.org/10.20849/aes.v1i1.9

Herrera S., \& Murry, K. (2014). Mastering ESL/EFL Methods: Differentiated Instruction for Culturally and Linguistically Diverse (CLD) students. (3rd Ed.). New Jersey, NJ: Pearson.

Howard, J. R. (2004). What Does Research Tell Us about Classroom Discussion? In J. R. Howard (Ed.), Discussion in the College Classroom: Applications for Sociology Instruction. Washington, DC: American Sociological Association.

Huiyin, L. (2016). On Guidelines for College English Teaching and Challenges for College English Teachers. English Language Teaching, 9(1), 77-87. http://doi.org/10.5539/elt.v9n1p77

Kim, S. (2006). Academic oral communication needs of East Asian international graduate students in non-science and non-engineering fields. English for Specific Purposes, 25(4), 479-489. https://doi.org/10.1016/j.esp.2005.10.001

Krashen, S. D. (1982). Principles and Practice in Second Language Acquisition. Retrieved from http://www.sdkrashen.com/content/books/principles_and_practice.pdf

Lang, J. M. (2017, March 13). The Distracted Classroom. [Web log post]. Retrieved from https://www.chronicle.com/article/The-Distracted-Classroom/239446 
Lee, J., \& Martin, L. (2017). Investigating Students' Perceptions of Motivating Factors of Online Class Discussions. The International Review of Research in Open and Distributed Learning, 18(5), 1492-3831. https://doi.org/10.19173/irrodl.v18i5.2883

Mak, B. (2011). An exploration of speaking-in-class anxiety with Chinese ESL learners. System, 39, 202-214. https://doi.org/10.1016/j.system.2011.04.002

Mart, C. T. (2019). Reflections on Discussions of Literature: A Language Learning Environment to Promote Speaking Skills. The Journal of Social Sciences Research, 5(4), 846-850. https://doi.org/10.32861/jssr.54.846.850

Muller, N., Perret-Clermont, A., Tartas, V., \& Iannaccone, A. (2009). Psychosocial Processes in Argumentation. In N. Muller, A. Perret-Clermont (Eds.), Argumentation and Education: Theoretical Foundations and Practices (pp. 67-87). New York, NY: Springer. https://doi.org/10.1007/978-0-387-98125-3_3

Omatseye, B. (2007). The discussion teaching method: An interactive strategy in tertiary learning. Education, 128(1), 87-94.

Peng, J. E. (2012). Towards an ecological understanding of willingness to communicate in EFL classrooms in China. System, 40(2), 203-213. https://doi.org/10.1016/j.system.2012.02.002

Putiman, B. B. (2006). Student and teacher discourse during whole-class discussions of literature. Dissertation. University of Connecticut.

Qi, X. (2018). Teachers' Roles in China's EFL Classes Adopting the PAD Mode. Journal of Language Teaching and Research, 9(4), 798-802. http://dx.doi.org/10.17507/j1tr.0904.17

Rashid, S., Bao, G., \& Jelani, M. (2018). A Comparative Study about WTC Related to Different Majors in the Chinese EFL Context. IOSR Journal Of Humanities and Social Science, 23(6), 72-80. http:/doi.org/10.9790/0837-2306017280

Reticence in Chinese EFL students at varied proficiency levels. (2014). Retrieved March 16, 2019 from https://www.thefreelibrary.com/Reticence+in+Chinese+EFL+students+at+varied+proficiency+levels.-a0219012 099

Rigney, J. W. (1978). Learning strategies: A theoretical perspective. In H. F. O'Neil, Jr. (Ed.), Learning strategies (pp. 165-205). New York: Academic Press.

Savaşçi, M. (2014). Why are some students reluctant to use L2 in EFL speaking classes? An action research at tertiary level. Procedia-Social and Behavioral Sciences, 116, 2682-2686. https://doi.org/10.1016/j.sbspro.2014.01.635

The Learning Center: The University of North Carolina at Chapel Hill. (n.d.). Class discussion strategies. Retrieved from https://learningcenter.unc.edu/tips-and-tools/class-discussion-strategies/

Wang, P. (2010). A case Study of an in-class silent postgraduate Chinese student in London Metroplolitan University: A journey of Learning. TESOL Journal, 2, 207-214.

West, J. (2018). Raising the Quality of Discussion by Scaffolding Students' Reading. International Journal of Teaching and Learning in Higher Education, 30(1), 146-160.

Xie, X. (2010). Why are students quiet? Looking at the Chinese context and beyond. ELT Journal, 64(1), 10-20. https://doi.org/10.1093/elt/ccp060

Yan, D. (2017, Sep 06). How an Elite Chinese College Is Making Class Interesting Again [Web log post]. Retrieved from http://www.sixthtone.com/news/1000817/how-an-elite-chinese-college-is-making-class-interesting-again

Yang J., \& Yuen C. K. (2014). College English Teaching Methodology and Language Planning: A Pilot Study in Hefei, China. Procedia-Social and Behavioral Sciences, 118, 495-502. http://doi.org/10.1016/j.sbspro.2014.02.068

Zakrajsek, T. (Apr 13, 2017). Students Who Don’t Participate in Class Discussions: They are not all Introverts. [Web $\log \quad$ post]. Retrieved from https://www.scholarlyteacher.com/blog/students-who-dont-participate-in-class-discussions

Zhang, L. (n.d). English in China and Chine in the world. Retrieved from englishinchinaandchineseintheworld.doc

Zhao, W., Mok, I., \& Cao, Y. (2016). Curriculum reform in China: Student participation in classrooms using a 
reformed instructional model. International Journal of Educational Research, 75, 88-101. https://doi.org/10.1016/j.ijer.2015.10.005

Zhao, Y. (2007). Cultural Conflicts in an Intercultural Classroom Discourse and Interpretations from a Cultural Perspective. Intercultural Communication Studies, 2007. 